\title{
Living pharmacy in urban yards: Health care in the Amazon
}

\section{Farmácia viva em quintais urbanos: Atenção à saúde na Amazônia}

\author{
Gerciene de Jesus Miranda Lobato $\mathbb{D}^{1}$, Flávia Cristina Araújo Lucas ${ }^{2 *}$, Ely Simone Cajueiro \\ Gurgel $\mathbb{1}^{3}$, Carolina Mesquita Germano $\mathbb{D}^{4}$
}

${ }^{1}$ Doutoranda em Ciências Ambientais, Universidade Federal do Pará, Belém. Fone: (91) 98159-2598. E-mail: gercienelobato@ hotmail.com; ${ }^{2}$ Doutora em Ciências Biológicas, docente do Centro de Ciências Sociais e Educação/ Universidade do Estado do Pará, Belém. Fone: (91) 99981-3133. E-mail: copaldoc@yahoo.com.br; ${ }^{3}$ Doutora em Biologia Vegetal, Pesquisadora Titular III, Coordenação de Botânica/ Museu Paraense Emílio Goeldi, Belém. Fone: (91) 99991-1239. E-mail: esgurgel@ museu-goeldi.br; ${ }^{4}$ Doutora em Plantas Medicinais, Aromáticas e Condimentares, Universidade do Estado do Pará, Belém. Fone: (91) 98347-8226. E-mail: carolmgermano@ gmail.com

\section{A R T I G O}

Recebido: $23 / 10 / 2018$

Aprovado: 23/12/2018

Key words:

Medicinal plants

Quality of life

Biological activity

Abaetetuba - Brazil

Palavras-chave:

Plantas medicinais

Qualidade de vida

Atividade biológica

Abaetetuba - Brasil

\section{A B S T R A C T}

The ethnobotanical research group of in the Amazon in Universidade Estadual do Pará (Pará State University) has been studying the use of various plant species by traditional communities for the treatment and cure of diseases. This study aimed to identify the medicinal plants around the home most used in Bairro Mutirão, Abaetetuba, Pará, Brazil to correlate ethnopharmacological data with phytochemical studies, evaluating the contribution of these species to promote health in poor communities in the Amazon. There were non-participant observations, semi-structured interviews and guided tours in 189 yards. Phytochemical information was gathered from ScienceDirect, Scinfinder, Scopus, DataPlant, Hindawi Publishing Corporation. We identified 46 therapeutic species, particularly Aloe vera (L.) Burman. f.; Anacardium occidentale L.; Bixa orellana L.; Kalanchoe pinnata (Lam.) Pers.; Lippia alba (Mill.) N.E.Br. ex P. Wilson and, Morinda citrifolia L., noted in the scientific literature as having antitumor, soothing, antiinflammatory and antimicrobial potential, confirming their ethnopharmacological use in home yards in Abaetetuba. The medicinal flora around homes in the Amazon is a path to the conservation of plant diversity in urbanized environments and potentially to the discovery of new drugs.

\section{R E S U M O}

O Grupo de Pesquisa em Etnobotânica da Amazônia da Universidade Estadual do Pará, vem estudando o uso de várias espécies vegetais por comunidades tradicionais para o tratamento e cura de doenças. Este estudo teve como objetivo identificar as plantas medicinais mais utilizadas presentes nos quintais do Bairro Mutirão, Abaetetuba, Pará, Brasil, a fim correlacionar dados etnofarmacológicos com estudos fitoquímicos, avaliando a contribuição dessas espécies para promover a saúde em comunidades pobres da Amazônia. A pesquisa se deu por meio de observações não participantes, entrevistas semiestruturadas e visitas guiadas em 189 quintais. Informações fitoquímicas foram coletadas das bases ScienceDirect, Scinfinder, Scopus, DataPlant, Hindawi Publishing Corporation. Foram identificadas 46 espécies terapêuticas, das quais Aloe vera L. Burman. f.; Anacardium occidentale L.; Bixa orellana L.; Kalanchoe pinnata (Lam.) Pers.; Lippia alba (Mill.) N.E.Br. ex P. Wilson e Morinda citrifolia L., foram observadas na literatura científica como potencial antitumoral, calmante, anti-inflamatório e antimicrobiano, confirmando seu uso etnofarmacológico pelos moradores em Abaetetuba. A flora medicinal em torno de casas na Amazônia mantém a diversidade de plantas em ambientes urbanizados, contribuindo potencialmente para a descoberta de novas drogas.

According to the World Health Organization (WHO),

\section{INTRODUCTION}

Ethnobotanical surveys in local communities can investigate the potential of plant resources and forms of use by human societies, obtaining a wealth of information to pass on to future generations, providing for their survival needs (SILVA et al., 2015). traditional system based on medicinal plants is supported by about $75-80 \%$ of the world population, especially in developing countries, for primary health care due to better cultural acceptance, better toleration by the human body and lower side effects (WHO, 2008). Moreover, plants used for 
medicinal purposes are believed to be favorable to health, since people who use them have prior knowledge of their purpose, risks and benefits (ANTONIO et al., 2013; BADKE et al., 2012).

Many species with medicinal, food and, wood purpose could be cultivated in a portion of land near the house with easy access, which is defined, according to Siviero et al. (2011) , as home yards. This type of cultivation is a promising approach to enhancing household food security and wellbeing (GALHENA et al., 2013), biodiversity conservation (GALLUZZI et al., 2010), socio-cultural preservation (MAZUMDAR; MAZUMDAR, 2012).

In the Amazon, the maintenance of urban yards is related in various ways to the daily life of communities, with multiple meanings for private and collective life, representing much more than a functional and utilitarian space (LOBATO et al., 2017; TOURINHO; SILVA, 2016). Siviero et al. (2011) highlights the importance of maintaining home yards in large centers in the supply of food directly through the yards or via exchanges with neighbors and relatives.

The diversity of medicinal plants found in home yards in the Amazon is the source of life and survival for residents of communities in the municipality of Abaetetuba, Pará (MOURA et al., 2016). The health disorders that most affect the residents of Bairro Mutirão include skin inflammation, wound healing difficulties, lack of sleep, nervous behavioral states and skin and stomach cancer. These diseases indicate the needs of the population, and as recorded in the publication Brasil (2012), traditional medicine using plants is the recommended strategy to meet such demands. This study aimed to identify the medicinal plants around the home most used in Bairro Mutirão, Abaetetuba, Pará, Brazil to correlate the ethnopharmacological data with previous phytochemical studies, evaluating the contribution of these species to promoting health in poor communities in the Amazon.

\section{MATHERIAL AND METHODS}

The study was conducted in the Amazon municipality of Abaetetuba, Pará, Brazil (01²4'24"S 48 52'54"W, altitude $10 \mathrm{~m}$ - Figure 1), in the period of August 2013 to October 2014. Data were collected in 189 home yards using nonparticipant observation techniques, semi-structured interviews, guided tours and notes in field diary (ALBUQUERQUE et al., 2010).

Figure 1. Location map of the study area with a description of the streets of Bairro Mutirão.

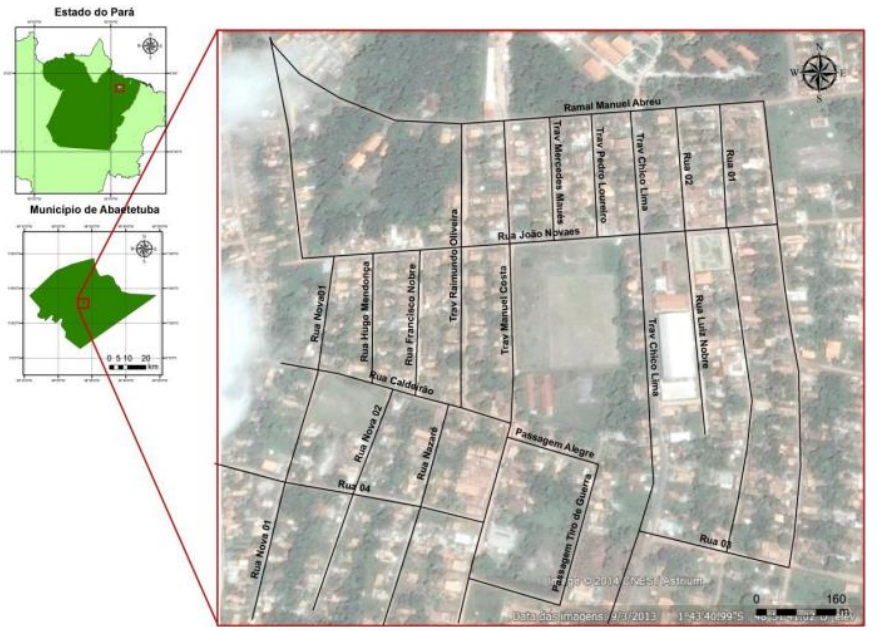

Source: LOBATO et al. (2017)
Bairro Mutirão was selected because it has more than 10 years of existence, allowing the study of formed and established yards, presence of vegetation around the houses and because the accessibility to residences. Authorization was requested with the community leadership to carry out the research, which culminated in the signing of the Term of Prior Consent (TAP) during a meeting with the residents.

The interviews were held with experts in the use of medicinal plants for healthcare in Bairro Mutirão in the guided tours, it was possible to go over the area for cultivating medicinal plants with the local experts to find out about the use of each species (ALBUQUERQUE et al., 2010).

The plants of the yards were photographed and identified by comparison with the images of plants deposited in MFS (herbarium of Universidade do Estado do Pará UEPA), and the scientific names were determined according to the Species List of the Flora of Brazil (2020). Phytochemical information was obtained from databases (ScienceDirect, Scinfinder, Scopus, DataPlant, Hindawi Publishing Corporation) and scientific journals as well.

The databases consultation occurred through the insertion of keywords (therapeutic indication, chemical composition, biological potential) in the search areas. Only the articles that presented information for the species most found in the backyards of the Bairro Mutirão were selected. After this initial screening, a table was created, using the software Microsoft Excel® - 2010 to organize the data collected.

\section{RESULTS AND DISCUSSION}

Forty-six therapeutic species (Table 1) were found in the yards, particularly Aloe vera L. Burman. f., Anacardium occidentale L., Bixa orellana L., Kalanchoe pinnata (Lam.) Pers., Lippia alba (Mill.) N.E.Br. ex P. Wilson and Morinda citrifolia L., the most cited by the local experts. They are species originating from various parts of the world, including Brazil, Asia, Madagascar and Africa. The ethnobotanic studies by Freitas et al. (2012), Silva et al. (2015) and, Moura et al. (2016) demonstrated the efficacy of these plants in the treatment of the illnesses mentioned here.

These six species are cultivated in yards and prepared using home recipes for health-related problems, such as wound healing, insomnia, for soothing and treating cancer (Table 2). These benefíts have been described Freitas et al. (2015) for Anacardium occidentale L. (inflammation, injuries, flu); Aloe vera (L.) Burman. f. (wound healing; inflammation; hemorrhoids, injuries, lice, cancer, stimulant), and Morinda citrifolia L. (diabetes, cholesterol, infections, inflammation). These data reveal and emphasize that humans conserve transgenerational knowledge to maintain their natural pharmacopoeias, even if they are in urbanized areas.

Table 1. Medicinal species found in the yards of Bairro Mutirão, Abaetetuba, Pará, Brazil.

\begin{tabular}{lcc}
\multicolumn{1}{c}{ Species } & $\begin{array}{c}\text { Number of } \\
\text { citations }\end{array}$ & $\begin{array}{c}\text { Frequency } \\
(\%)\end{array}$ \\
\hline $\begin{array}{l}\text { Bixa orellana } \text { L. } \\
\text { Anacardium occidentale L. }\end{array}$ & 39 & 11.5 \\
Lippia alba (Mill.) N.E.Br. ex P. & 26 & 7.7 \\
Wilson & 23 & 6.8 \\
Morinda citrifolia L. & 18 & 5.3 \\
Aloe vera (L.) Burman. f. & 16 & 4.7 \\
Kalanchoe pinnata (Lam.) Pers. & 16 & 4.7
\end{tabular}


Gerciene de Jesus Miranda Lobato et al.

Cymbopogon citratus (DC.) Stapf

Arrabidaea chica (Bonpl.) B.

Verl.

Eleutherine plicata Herb. Ex Klatt

Cinnamomum zeylanicum Blume

Mentha pulegium $\mathrm{L}$.

Vernonia condensata Baker

Ocimum campechianum Mill.

Costus spirali (Jacq.) Roscoe

Pedilanthus tithymaloides

Poit.

Zingiber officinale Roscoe

Ruta graveolens $\mathrm{L}$.

Mansoa alliacea (Lam.) A. H.

Gentry

Citrus aurantifolia Swingle

Gossypium barbadense L.

Plectranthus barbatus Andrews

Pluchea sagittalis (Lam.) Cabrera

Petiveria alliacea L.

Ayapana triplinervis (Vahl) R. M.

King \& H. Rob.

Chenopodium ambrosioides $\mathrm{L}$.

Phyllanthus niruri subsp.

lathyroides (Kunth) G. L.

Webster

\section{$4.4 \quad$ Portulaca pilosa L.}

Ocimum gratissimum L.

Libidibia ferrea (Mart. ex Tul.)

L.P. Queiroz

4.1

Jatropha gossypiifolia L.

Coffea arabica $\mathrm{L}$.

Coix lacryma-jobi $\mathrm{L}$.

Pogostemon heyneanus Benth.

Jatropha curcas L.

Coleus sp.

Peperomia pellucida (L.) Kunth

Ocimum micranthum Willd.

Sesamum orientale $\mathrm{L}$.

(Lour.)

Plectranthus amboinicus (Lour.) 1

Vismia guianensis (Aubl.) Choisy

Ocimum minimum L.

Justicia pectoralis Jacq.

Alternanthera tenella Colla

Bauhinia forficata Link

Bidens pilosa L.

Hemigraphis colorata (Blume)

1.2

Hallier $\mathrm{f}$.

Total

1.2

100.0

Table 2. Pharmacological data of the most cited species found in the yards of Bairro Mutirão, Abaetetuba, Pará, Brazil.

\begin{tabular}{|c|c|c|c|}
\hline $\begin{array}{l}\text { Species/Famíly/ } \\
\text { Ethnospecies }\end{array}$ & $\begin{array}{l}\text { Therapeutic } \\
\text { indication }\end{array}$ & Part used/form of use & Pharmacology \\
\hline $\begin{array}{l}\text { Aloe vera (L.) Burman. } \\
\text { f./Xanthorrhoeaceae/ } \\
\text { Babosa }\end{array}$ & $\begin{array}{l}\text { Skin and stomach } \\
\text { cancer }\end{array}$ & $\begin{array}{l}\text { 1. Leaves. Wash well, and then heat } \\
\text { over a flame until wilted. Next, place } \\
\text { leaves in a tea of cashew tree leaves. } \\
\text { Use this mixture to wash the skin. } \\
\text { 2. Leaves. Juice of leaves to treat } \\
\text { stomach cancer. }\end{array}$ & $\begin{array}{l}\text { Antimicrobial (FREITAS et al., } \\
\text { 2014; GUPTA et al., 2010). } \\
\text { Antigenotoxic and antitumorigenic } \\
\text { (ESMAT et al., 2006; KIM et al., } \\
\text { 1999). }\end{array}$ \\
\hline $\begin{array}{l}\text { Anacardium occidentale } \\
\text { L./Anacardiaceae/Caju }\end{array}$ & Wound healing & Bark. Tea. & $\begin{array}{l}\text { Anti-inflammatory; Antimicrobial } \\
\text { (CHAVES et al., 2010; SILVA et } \\
\text { al., 2007). }\end{array}$ \\
\hline $\begin{array}{l}\text { Bixa orellana } \\
\text { L./Bixaceae/Urucum }\end{array}$ & Soothing for heart & Seeds. Add to water to drink. & $\begin{array}{l}\text { Antifebrile (TAYLOR, 1998). } \\
\text { Antimicrobial (FLEISCHER et al., } \\
\text { 2003). }\end{array}$ \\
\hline $\begin{array}{l}\text { Kalanchoe pinnata (Lam.) } \\
\text { Pers./Crassulaceae/Pirarucu }\end{array}$ & Wound healing & Leaves. Place on wound. & $\begin{array}{l}\text { Anti-inflammatory (SOUSA et al., } \\
\text { 2005); } \quad \text { Leishmanicide } \\
\text { (MUZITANO et al., 2006). }\end{array}$ \\
\hline $\begin{array}{l}\text { Lippia alba (Mill.) N.E.Br. } \\
\text { ex P. Wilson /Verbenaceae/ } \\
\text { Erva cidreira }\end{array}$ & Soothing/sleep & Leaves. Tea. & $\begin{array}{l}\text { Soothing (SILVA et al., 2006). } \\
\text { Sedative and motor relaxant } \\
\text { (VALE et al., 2002). }\end{array}$ \\
\hline $\begin{array}{l}\text { Species/Famíly/ } \\
\text { Ethnospecies }\end{array}$ & $\begin{array}{l}\text { Therapeutic } \\
\text { indication }\end{array}$ & Part used/form of use & Pharmacology \\
\hline $\begin{array}{l}\text { Morinda citrifolia } \\
\text { L./Rubiaceae/Noni }\end{array}$ & Cancer & Fruit. Add to water to drink. & $\begin{array}{lr}\text { Antitumor } & \text { (ARPORNSUWAN; } \\
\text { PUNJANON, } & 2006 ; \\
\text { HIRAAZUMI; } & \text { FURUSAWA, } \\
\text { 1999). } & \\
\text { Anti-inflammatory; } & \text { hypotensive; } \\
\text { antimicrobial (ELKINS, 1997). }\end{array}$ \\
\hline
\end{tabular}

Chemical composition of species and proven biological activity

Aloe vera (L.) Burman f. (Xanthorrhoeaceae)

Aloe L. genus is a monoecious, perennial species with shallow roots. Aloe species are mostly inhabitants of arid climates, and are widely distributed in Africa, India, and other arid areas (SALEHI et al., 2018). It is used by the population of Bairro Mutirão for the prevention and treatment of cancer. The parenchymatous cells, in the fresh leaves of Aloe vera, secrete a colorless mucilaginous gel that contains $98-99 \%$ 
water and 1-2\% active compounds like Aloesin, Aloin, Aloeemodin, Aloe-mannan, Flavonoids, Saponin, Sterols, Amino acids, Vitamins, anthraquinones, quinones, pyrimidines, alkaloids, and mucopolysaccharides (FREITAS et al., 2014; JAIN et al., 2016; NEJATZADEH-BARANDOZI, 2013). The species has been reported for multiple biological properties such as antibacterial and antimicrobial, antitumor, anti-inflammatory, anti-arthritic, anti-rheumatoid, anticancer, and antidiabetic activities (BOUDREAU et al., 2013; KAMMOUN et al., 2011; RADHA; LAXMIPRIYA, 2015).

The extract of Aloe vera leaves tested by Kim et al. (1999) in rat liver cells against the action of benzopyrene demonstrated an antigenotoxic and antitumorigenic effect in vitro and thus may be considered for its potential in cancer chemoprevention. Esmat et al. (2006) discussed the cytotoxic activity of aloin, an Aloe natural anthracycline, against two human breast cancer cell lines, suggesting that this substance may be used in the treatment of tumors.

\section{Anacardium occidentale L. (Anacardiaceae)}

This is a native tree characteristic of North and Northeast Brazil. The leaves are used as infusion in the treatment of gastrointestinal disorders, mouth ulcers and throat problems, in West Africa and South America (AJILEYE et al., 2015). This species has phenolics and catecholics, catechin, epicatechin, tannins, alkaloids, cardol, cardanol, anacardic acid, catechin, epicatechin, carotene (CHAVES et al., 2010; TROX et al., 2011; YULIANA et al., 2014).

Fractionation of the ethanol extract of the stem bark of Anacardium occidentale resulted in the isolation of anacardics with an unsaturated side chain (monoene and diene), as free steroids, glycosylated and esterified with fatty acids, while the ethanol extract of the seed coat showed the steroids sitosterol and stigmasterol, the pentacyclic triterpenoids lupeol and $\beta$-amyrin and the flavanols catechin and epicatechin, substances that significantly indicate the antioxidant potential of this species (CHAVES et al., 2010).

Bioactive compounds from irradiated leaf extracts of Anacardium occidentale showed high antimicrobial activity against Staphylococcus aureus and multidrug-resistant, in vitro (SANTOS et al., 2018). Blood glucose levels in rats showed that treatment with the extracts of $A$. occidentale leaves was more effective than with glyburide (synthetic antidiabetic drug), confirming its antidiabetic effect of this species (OKPASHI et al., 2014). Trabulsi Filho et al. (2013) reported that the hydroalcoholic extracts of $A$. occidentale leaves not only had strong antioxidant activity but also a moderate cytotoxic effect on trophozoites of Giardia lamblia. It was also demonstrated that extractive procedure and solvent are variables that influence the extracts obtained and thus yields and antioxidant and giardicidal activities.

\section{Bixa orellana L. (Bixaceae)}

This species is native to Brazil and is cultivated in other parts of South and Central America (VILAR et al., 2014). It is commonly found as an ornamental plant in Brazil (CUSTODIO et al., 2002), and its seeds produce one of the most widely used dyes worldwide, not only in food but also in the textiles, paints and cosmetics (VILAR et al., 2014).

Red and yellow pigments extracted from seed arils are rich in carotenoids including $\alpha$-bixin, $\beta$-bixin, $\alpha$-norbixin and $\beta$-norbixin, besides a volatile oil rich in all-E-geranylgeraniol, oxygenated monoterpenes and sesquiterpenes, and flavonoids (LORENZI; MATOS, 2008; MORS et al., 2000; SOUSA et al., 1991). Bixin, first isolated from Bixa orellana seeds in 1875 and 1961 belong to the class of natural apocarotenoids (VILAR et al., 2014). With regard to pharmacological properties, it has been described antifungal, antibacterial, antimalarial and anti-inflammatory activities (GIORGI et al., 2013; MARIATH et al., 2009; YOKE KEONG et al., 2011).

\section{Kalanchoe pinnata (Lam.) Pers. (Crassulaceae)}

This species is a succulent herb from Madagascar, and the Kalanchoe pinnata specie possess polyphenolic compounds such as flavonoids and phenolic acid as the main compounds (BOGUCKA-KOCKA et al., 2018; COSTA et al., 2008). The chemical composition $K$. pinnata is characterized mainly by the presence of quercetin glycosides (MUZITANO et al., 2011).

Muzitano et al. (2006) analyzed the aqueous extract of Kalanchoe pinnata leaves and found the presence of a kaempferol diglycoside called kapinnatoside, identified as kaempferol 3-O- $\alpha$-L-arabinopyranosyl $\quad(1 \rightarrow 2) \quad \alpha$-Lrhamnopyranoside (1), and two uncommon flavonols and flavone glycosides, namely quercetin 3-O- $\alpha-\mathrm{L}-$ arabinopyranosyl $(1 \rightarrow 2) \alpha$-L-rhamnopyranoside $(2)$ and 4', 5dihydroxy-3',8-dimethoxyflavone 7-O- $\beta$-d-glucopyranoside (3). These constituents appear to be important in the leishmanicidal activity of $K$. pinnata. The aqueous extract of $K$. pinnata flowers has been shown to produce dosedependent inhibition of acetic acid-induced writing in rats, indicating antinociceptive activity (FERREIRA et al., 2014).

\section{Lippia alba (Mill.) N.E.Br. ex P. Wilson (Verbenaceae)}

This aromatic shrub is found throughout tropical and subtropical America, widely distributed throughout Brazil, growing spontaneously on abandoned land or cultivated medicinal gardens (AGUIAR; COSTA, 2005). It has essential oils rich in mono- and sesquiterpenes (AGUIAR et al., 2008), and the chemical composition Lippia L. shows volatile constituents, alkaloids, tannins, flavonoids, naphthoquinones and iridoids (GOMES et al., 2011).

Its aromatic metabolites have been characterized in the country, presenting different chemical markers with pharmacological properties already known, such as analgesic, sedative and antifungal (CAMILLO, 2016). Actions of citral, limonene and myrcene (essential oil constituents of a Lippia alba chemotype) on the central nervous system, evaluated by Vale et al. (2002), showed that all these components have sedative and motor relaxing effects. At high doses, produced a potentiation of pentobarbital-induced sleep in mice, more intense in the presence of citral, but none of the components showed an anxiolytic effect (VALE et al., 2002).

\section{Morinda citrifolia L. (Rubiaceae)}

Originally from Southeast Asia, this plant was recently introduced in Brazil with strong commercial appeal because of the beneficial features attributed to it (MATOSO et al., 2013). It is known for producing alkaloids, iridoids, anthraquinones, and flavonoids (ROSA et al., 2010; TINTINO et al., 2015). Morinda citrifolia has phenolic groups in the form of anthraquinones and their glycosides (damnacanthal, morindone, morindine, scopoletin, alizarin, austrocortinin, rubiadin). 
A fraction rich in polysaccharides, obtained from fruit juice by ethanol precipitation, showed antitumor activity in Lewis lung carcinoma model in rats. The precipitate also stimulated the release of certain cytokines, such as TNF- $\alpha$, IL-1 $\beta$, IL-10 and IF- $\gamma$ (HIRAAZUMI; FURUSAWA, 1999). Arpornsuwan and Punjanon (2006) showed the growthinhibition of breast cancer and neuroblastoma cell lines in vitro by a methanol extract of the fruits of Morinda L. at a concentration of $0.1 \mathrm{mg} / \mathrm{ml}$. Pharmacological investigations have demonstrated that the roots of Morinda citrifolia possess an antihypertensive action and that an alcoholic extract has an in vitro antispasmodic effect (MOOKHTIAR et al., 2018).

\section{CONCLUSION}

A total of 46 medicinal species were identified, of which Aloe vera L. Burman. f .; Anacardium occidentale L.; Bixa orellana L.; Kalanchoe pinnata (Lam.) Pers.; Lippia alba (Mill.) N.E.Br. ex P. Wilson and, Morinda citrifolia L., were observed in the scientific literature with antitumor, soothing, anti-inflammatory and antimicrobial potential, confirming its ethnopharmacological use by residents of Bairro Mutirão.

There are a variety of substances that range from the compounds most frequently found in plants to others of highly specific molecular formulas, a fact that contributes to the knowledge of pharmacological properties still unknown or little studied. Thus, the medicinal flora in the yards of Amazon people also represents a way for the discovery of new drugs, or extension of their use.

\section{REFERENCES}

AGUIAR, J. S.; COSTA, M. C. C. D. Lippia alba (Mill.) N.E. Brown (Verbenaceae): levantamento de publicações nas áreas química, agronômica e farmacológica, no período de 1979 a 2004. Revista Brasileira de Plantas Medicinais, v. 8, n. 1, p. 79-84, 2005.

AGUIAR, J. S.; COSTA, M. C. C. D.; NASCIMENTO, S. C.; SENA, K. X. F. R. Atividade antimicrobiana de Lippia alba (Mill.) N. E. Brown (Verbenaceae). Revista Brasileira de Farmacognosia, v. 18, n. 3, p. 436-440, 2008. 10.1590/S0102695X2008000300018

AJILEYE, O. O.; OBUOTOR, E. M.; AKINKUNMI, E. O.; ADEROGBA, M. A. Isolation and characterization of antioxidant and antimicrobial compounds from Anacardium occidentale L. (Anacardiaceae) leaf extract. Journal of King Saud University, v. 27, p. 244-52, 2015. 10.1016/j.jksus.2014.12.004

ALBUQUERQUE, U. P.; LUCENA, R. F. P; CUNHA, L. V. F. C. Métodos e técnicas na pesquisa etnobiológica e etnoecológica. (Coleção Estudos e Avanços). NUPPEA: Recife. 2010. 559 p.

ANTONIO, G. D.; TESSER, C. D.; MORETTI-PIRES, R. O. Contributions of medicinal plants to care and health promotion in primary healthcare. Interface - Comunicação, Saúde, Educação (Botucatu), v.17, n. 46, p. 615-633, 2013. 10.1590/S1414-32832013005000014.
ARPORNSUWAN, T.; PUNJANON, T. Tumor cell-selective antiproliferative effect of the extract from Morinda citrifolia fruits. Phytotherapy Research, v. 20, n. 6, p. 515-517, 2006. 10.1002/ptr.1902

BADKE, M. R.; BUDÓ, M. D. L. D.; ALVIM, N. A. T.; ZANETTI, G. D.; HEISLER, E. V. Saberes e práticas populares de cuidado em saúde com o uso de plantas medicinais. Texto \& Contexto - Enfermagem, v. 21, n. 2, p. 363-370, 2012. 10.1590/S0104-07072012000200014.

BOGUCKA-KOCKA, A.; ZIDORN, C.; KASPRZYCKA, M.; SZYMCZAK, G.; SZEWCZYK, K. Phenolic acid content, antioxidant and cytotoxicactivities of four Kalanchoe s̈pecies. Saudi Journal of Biological Sciences, v. 25, n. 4, p. 622-630, 2018. 10.1016/j.sjbs.2016.01.037.

BOUDREAU, M. D.; MELLICK, P. W.; OLSON, G. R.; FELTON, R. P.; THORN, B. T.; BELAND, F. A. Clear Evidence of Carcinogenic Activity by a Whole-Leaf Extract of Aloe barbadensis Miller (Aloe vera) in F344/N Rats. Toxicological Sciences, v. 131, n. 1, p. 26-39, 2013. $10.1093 /$ toxsci/kfs275.

BRASIL. Ministério da Saúde. Secretaria de Atenção à Saúde. Departamento de Atenção Básica. Práticas integrativas e complementares: plantas medicinais e fitoterapia na Atenção Básica/Ministério da Saúde. Secretaria de Atenção à Saúde. Departamento de Atenção Básica - Brasília: Ministério da Saúde, 156 p. 2012.

CAMILLO, F. C. Lippia alba (Mill.) N.E. Br. ex Britton \& P. Wilson uma espécie nativa promissora para a introdução em programas nacionais de plantas medicinais e fitoterápicos. Revista Fitos, v. 10, n. 4,, p. 1-62, 2016. 10.5935/24464775.20160042.

CHAVES, M. H.; CITO, A. M. DAS G. L.; LOPES, J. A. D.; COSTA, D. A. D.; OLIVEIRA, C. A. A. D.; COSTA, A. F.; BRITO JÚNIOR, F. E. M. Fenóis totais, atividade antioxidante e constituintes químicos de extratos de Anacardium occidentale L., Anacardiaceae. Revista Brasileira de Farmacognosia, v. 20, n. 1, p. 106-112, 2010. 10.1590/S0102-695X2010000100021.

COSTA, S. S.; MUZITANO, M. F.; CAMARGO, L. M. M.; COUTINHO, M. A. S. Therapeutic potential of Kalanchoe species: flavonoids and other secondary metabolites. Natural Product Communications, v. 3, n. 12, p. 2151-2164. 2008.

CUSTÓDIO, C. C.; MACHADO-NETO, N. B.; CASEIRO, R. F.; IKEDA, M.; BOMFIM, D. C. Germinação de sementes de urucum (Bixa orellana L.). Revista Brasileira de Sementes, v. 24, n. 1, p. 197-202, 2002.

ELKINS, R. Noni (Morinda citrifolia) la hierba preciada del pacífico sur. Pleasant Grove, Utah: Woodland Publishing; 1997. p. 31.

ESMAT, A. Y.; TOMASSETO, C.; RIO, M. C. Cytotoxicity of a natural anthraquinone (Aloin) against human breast cancer cell lines with and without ErbB-2: topoisomerase 
IIalpha coamplification. Cancer Biology \& Therapy, v. 5, p. 97-103, 2006.

FERREIRA, R. T.; COUTINHO, M. A. S.; MALVAR, D. D. C.; COSTA, E. A.; FLORENTINO, I. F.; COSTA, S. S.; VANDERLINDE, F. A. Mechanisms underlying the antinociceptive, antiedematogenic, and anti-inflammatory activity of the main flavonoid from Kalanchoe pinnata. Evidence-Based Complementary and Alternative Medicine, v. 2014, p. 1-8, 2014. 10.1155/2014/429256

FLEISCHER, T. C.; AMEADE, E. P. K.; MENSAH, M. L. K.; SAWER, I. K. Antimicrobial activity of the leaves and seeds of Bixa orellana. Fitoterapia, v. 74, n. 1, p. 136-138, 2003. 10.1016/S0367-326X(02)00289-7

FLORA DO BRASIL 2020 em construção. Jardim Botânico do Rio de Janeiro. Disponível em: <http://floradobrasil.jbrj.gov.br/ >. Acesso em: 11 Ago. 2014.

FREITAS, A. V. L.; COELHO, M .D. F. B.; MAIA, S. S. S.; AZEVEDO, R. A. B. de. Plantas medicinais: um estudo etnobotânico nos quintais do Sítio Cruz, São Miguel, Rio Grande do Norte, Brasil. Revista Brasileira de Biociências, v. 10, n. 1, p. 48-59, 2012.

FREITAS, V. S.; RODRIGUES, R. A. F.; GASPI, F. O. G. Pharmacological activities of Aloe vera (L.) Burm. f. Revista Brasileira de Plantas Medicinais, v. 16, n. 2, p. 299-307, 2014. 10.1590/S1516-05722014000200020

FREITAS, A. V. L.; COELHO, M. F. B.; PEREIRA, Y. B.; FREITAS NETO, E. C.; AZEVEDO, R. A. B. Diversidade e usos de plantas medicinais nos quintais da comunidade de São João da Várzea em Mossoró, RN. Revista Brasileira de Plantas Medicinais, v. 17, n. 4, supl. 2, p. 845-856, 2015. 10.1590/1983-084X/14_080.

GALHENA, D. H; FREED, R.; MAREDIA, K. M. Home Gardens: a promising approach to enhance household food security and wellbeing. Agriculture \& Food Security, v. 2, n. 8, 2013. 10.1186/2048-7010-2-8

GALLUZZI , G.; EYZAGUIRRE, P.; NEGRI, V. Home gardens: neglected hotspots of agro-biodiversity and cultural diversity. Home gardens: neglected hotspots of agrobiodiversity and cultural diversity, v. 19, n. 13, p. 3635-3654, 2010. 10.1007/s10531-010-9919-5

GIORGI, A.; MARINIS, P. de; GRANELLI, G.; CHIESA, L. M.; PANSERI, A. Secondary metabolite profile, antioxidant capacity, and mosquito repellent activity of Bixa orellana from Brazilian Amazon region. Journal of Chemistry, v. 2013, 2013. 10.1155/2013/409826

GOMES, S. V. F.; NOGUEIRA, P. C. L.; MORAES, V. R. S. Aspectos químicos e biológicos do gênero Lippia enfatizando Lippia gracilis Schauer. Eclética Química, v. 36, n. 1, p. 6477, 2011. 10.1590/S0100-46702011000100005

GUPTA, R.; THAKUR, B.; SINGH, P.; SINGH, H. B.; SHARMA, V. D.; KATOCH, V. M.; CHAUHAN, S. V. S. Anti-tuberculosis activity of selected medicinal plants against multi-drug resistant Mycobacterium tuberculosis isolates. Indian Journal of Medical Research, v. 131, p. 80913, 2010.

HIRAAZUMI, A.; FURUSAWA, E. An immunomodulatory polysaccharide-rich substance from the fruit juice of Morinda citrifolia(Noni) with antitumor activity. Phytotherapy Research, v. 13, n. 5, p. 380-387, 1999.

JAIN, S., RATHOD, N.; NAGI, R.; SUR, J.; LAHEJI, A.; GUPTA, N.; AGRAWAL, P.; PRASAD, S. Antibacterial Effect of Aloe Vera Gel against Oral Pathogens: An In-vitro Study. Journal of Clinical and Diagnostic Research, v. 10, n. 11, p. ZC41-ZC44, 2015. 0.7860/JCDR/2016/21450.8890.

KAMMOUN, M.; MILADI, S.; ALI, Y. B.; DAMAK, M.; GARGOURI, Y. BEZZINE, S. In-vitro study of the PLA2 inhibition and antioxidant activities of aloe vera leaf skin extracts. Lipids in Health and Disease, v. 10, n. 30, 2011. 10.1186/1476-511X-10-30.

KIM, H. S.; KACEW, S.; LEE, B. M. In vitro chemopreventive effects of plant polysaccharides (Aloe barbadensis Miller, Lentinus edodes, Ganoderma lucidum and Coriolus versicolor). Carcinogenesis, v. 20, p. 16371640, 1999.

LOBATO, G. de J. M. ; LUCAS, F. C. A.; TAVARESMARTINS, A. C. C.; JARDIM, M. A. G.; MARTORANO, L. G. Diversidade de uso e aspectos socioambientais de quintais urbanos em Abaetetuba, Pará, Brasil. Revista Brasileira de Agroecologia, v. 2, n. 2, p. 95-105, 2017.

LORENZI, H.; MATOS, F. J. de A. Plantas medicinais no Brasil: nativas e exóticas. 2ed. - Nova Odessa, SP: Instituto Plantarum, 2008. 512p.

MARIATH, I. R.; FALCAO, H. S.; BARBOSA-FILHO, J. M.; SOUSA, L. C. F.; TOMAZ, A. C. A.; BATISTA, L. M.; DINIZ, M. F. F. M.; ATHAYDE-FILHO, P. F.; TAVARES, J. F.; SILVA, M. S.; CUNHA, E. V. L. Plants of the American continent with antimalarial activity. Revista Brasileira de Farmacognosia, v. 19, n. 1a, p. 158-192, 2009. 10.1590/S0102-695X2009000100026.

MATOSO, L. M. L.; MELO, C. C. R. de; MENEZES, L. M. D. C. S.; OLIVEIRA, L. E. de; OLIVEIRA, K. K. D. de. As Características e a Utilização do Noni (Morinda Citrifolia). C\&D-Revista Eletrônica da Fainor, v. 6, n. 1, p. 42-50, 2013.

MAZUMDAR, S.; MAZUMDA, S. Immigrant home gardens: places of religion, culture, ecology, and family. Landscape and Urban Planning, v. 105, p. 258-265, 2012. doi.org/10.1016/j.landurbplan.2011.12.020.

MOOKHTIAR, H.; HEGDE, $\quad$ V.; SHANMUGASUNDARAM, S. Morinda citrifolia: A Fruit to Future Endodontics. World Journal of Dentistry, v. 9, n. 2, p. 145-148, 2018. 
MORS, W. B.; RIZZINI, C. T.; PEREIRA, N. A. Medicinal plants of Brazil. Reference publications, Inc., Algonac, Michigan, 2000. 501p.

MOURA, P. H. B. de; LUCAS, F. C. A.; TAVARESMARTINS, A. C. C.; LOBATO, G. de J. M.; GURGEL, E. S. C. Etnobotânica de chás terapêuticos em Rio Urubueua de Fátima, Abaetetuba-Pará, Brasil. Biotemas, v. 29, n. 2, p. $77-$ 88, 2016. 10.5007/2175-7925.2016v29n2p77.

MUZITANO, M. F.; TINOCO, L. W.; GUETTE, C.; KAISER, C. R.; ROSSI-BERGMANN, B.; COSTA, S. S. The antileishmanial activity assessment of unusual flavonoids from Kalanchoe pinnata. Phytochemistry, v. 67, n. 18, p. 2071-2077, 2006. 10.1016/j.phytochem.2006.06.027.

MUZITANO, M. F.; BERGONZI, M. C.; MELO, G. O. de; LAGE, C. L. S.; BILIA, A. R.; VINCIERI, F. F.; ROSSIBERGMANN, B.; COSTA, S. S. Influence of cultivation conditions, season of collection and extraction method on the content of antileishmanial flavonoids from Kalanchoe pinnata. Journal of Ethnopharmacology, v. 133, n. 1, p. 132137, 2011. 10.1016/j.jep.2010.09.020.

NEJATZADEH-BARANDOZ, F. Antibacterial activities and antioxidant capacity of Aloe vera. Organic and Medicinal Chemistry Letters, v. 3, n. 5, 2013. 10.1186/2191-2858-3-5.

OKPASHI, V. E.; BAYIM, B. P. R.; OBI-ABANG, M. Comparative effects of some medicinal plants: Anacardium occidentale, Eucalyptus globulus, Psidium guajava, and Xylopia aethiopica extracts in alloxan-induced diabetic male wistar albino rats. Biochemistry research international, v. 2014 , p. $1-14$, 2014. 10.1155/2014/203051

RADHA, M. H.; LAXMIPRIYA, N. P. Evaluation of biological properties and clinical effectiveness of Aloe vera: A systematic review. Journal of Traditional and Complementary Medicine, v. 5, n. 1, p. 21-26, 2015. 10.1016/j.jtcme.2014.10.006.

ROSA, E. A. da; SILVA, B. C. E.; SILVA, F. M. da; TANAKA, C. M. A.; PERALTA, R. M.; OLIVEIRA, C. M. A. de; KATO, L.; FERREIRA, H. D.; SILVA, C. C. da. Flavonoides e atividade antioxidante em Palicourea rigida Kunth, Rubiaceae. Revista Brasileira de Farmacognosia, v. 20 , n. 4, p. 484-488, 2010. 10.1590/S0102695X2010000400004.

SALEHI, B.; ALBAYRAK, S.; ANTOLAK, H.; KREGIEL, D.; PAWLIKOWSKA, W.; SHARIFI-RAD, M.; UPRETY, Y.; FOKOU, P. V. T.; YOUSEF, Z.; ZAKARIA, Z. A.; VARONI, E. M.; SHAROPOV, F.; MARTINS, N.; IRITI, M.; SHARIFI-RAD, J. Aloe Genus Plants: From Farm to Food Applications and Phytopharmacotherapy. International Journal of Molecular Science, v. 19, n 9, p. 2843, 2018. 10.3390/ijms 19092843 .

SANTOS, G. H. F. dos; AMARALA, A.; SILVA, E. B. da. Antibacterial activity of irradiated extracts of Anacardium occidentale L. on multiresistant strains of Staphylococcus aureus. Applied Radiation and Isotopes, v. 140, p 327-332, 2018. 10.1016/j.apradiso.2018.07.035.
SILVA, C. G.; MARINHO, M. G. V.; LUCENA, M. F. A.; COSTA, J. G. M. Levantamento etnobotânico de plantas medicinais em área de Caatinga na comunidade do Sítio Nazaré, município de Milagres, Ceará, Brasil. Revista Brasileira de Plantas Medicinais, v. 17, n. 1, p. 133-142, 2015. 10.1590/1983-084X/12_055.

SILVA, J. G; SOUZA, I. A; HIGINO, J. S.; SIQUEIRAJUNIOR, J. P.; PEREIRA, J. V.; PEREIRA, M. D. S. V. Atividade antimicrobiana do extrato de Anacardium occidentale Linn. em amostras multiresistentes de Staphylococcus aureus. Rev. bras. farmacogn. v.17, n.4, p.572-577, 2007. 10.1590/S0102-695X2007000400016.

SILVA, N. A.; OLIVEIRA, F. F.; COSTA, L. C. B.; BIZZO, H. R.; OLIVEIRA, R. A. Caracterização química do óleo essencial da erva cidreira (Lippia alba (Mill.) NE Br.) cultivada em Ilhéus na Bahia. Rev. bras. plantas med. v.8, n.3, p.52-55, 2006

SIVIERO, A.; DELUNARDO, T.A.; HAVERROTH, M.; OLIVEIRA, L.C. de; MENDONÇA, A.M.S. Cultivo de Espécies Alimentares em Quintais Urbanos de Rio Branco, Acre, Brasil. Acta Botanica Brasilica, v. 25, n. 3, p. 549-556, 2011. 10.1590/S0102-33062011000300006.

SOUSA, M. P.; MATOS, M. E. O.; MATOS, F. J. de A.; MACHADO, M. I. L.; CRAVEIRO, A. A. Constituintes químicos de plantas medicinais brasileiras. Imprensa Universitaria/ UFC, Fortaleza, 1991. 416p.

SOUSA, P. J. C.; ROCHA, J. C. S.; PESSOA, A. M.; ALVES, L. A. D.; CARVALHO, J. C. T. Preliminar study of the anti-inflammatory activity of Bryophillum calycinum Salisb. Revista brasileira de farmacognosia, v.15, n.1, p.6064, 2005. 10.1590/S0102-695X2005000100013

TAYLOR, L. Herbal secrets of the Rainforest. Prima Health Publishing, Rocklin, CA. 1998. 315p.

TINTINO, S. R.; NETO, A. A. de C.; MENEZES, I. R. A.; OLIVEIRA, C. D. de M.; COUTINHO, H. D. M. Antimicrobial activity and combined effects on antifungal and antibacterial drugs the fruit of Morinda citrifolia L. Acta Biológica Colombiana, v. 20, n. 3, p. 193-200, 2015. 10.15446/abc.v20n3.45601.

TOURINHO, H. L. Z.; SILVA, M. G. A. C. da. Quintais urbanos: funções e papéis na casa brasileira e amazônica, Bol. Mus. Para. Emílio Goeldi. Cienc. Hum., Belém, v. 11, n. 3, p. 633-651, 2016. 10.1590/1981.81222016000300006.

TRABULSI FILHO F. A.; ANDRADE, K. C. de S.; SILVA, E. C. da; CASTRO, A. T. O.; BATISTA, M. C. A.; RIBEIRO, M. N. de S.; AMARAL, F. M. M. do. Estudo de padronização de extratos de Anacardium occidentale L. na pesquisa e desenvolvimento de fitoterápicos giardicidas. Cadernos de Pesquisa, v. 20, n. especial, p. 7-15, 2013. 10.18764/2178-2229.v20n.especialp7-15.

TROX, J.; VADIVEL, V.; VETTER, W.; STUETZ, W.; KAMMERER， D.R.; CARLE， R.; SCHERBAUM， V.; 
GOLA, U.; NOHR, D.; BIESALSKI, H. K. Catechin and epicatechin in testa and their association with bioactive compounds in kernels of cashew nut (Anacardium occidentale L). Food Chemistry, v. 128, n. 4, p. 1094-1099, 2011. 10.1016/j.foodchem.2011.04.018

VALE, T. G.; FURTADO, E. C.; SANTOS, J. G.;VIANA, G. S. B. Central effects of citral, myrcene and limonene, constituents of essential oil chemotypes from Lippia alba (Mill.) N.E. Brown. Phytomedicine, v. 9, n. 8, p. 709-714, 2002. 10.1078/094471102321621304.

VILAR, D. A.; VILAR, M. S. A.; MOURA, T. F. A. L.; RAFFIN, F. N.; OLIVEIRA, M. R.; FRANCO, C. F. O.; ATHAYDE-FILHO, P. F.; DINIZ, M. F. F. M.; BARBOSAFILHO, J. M. Traditional uses, chemical constituents, and biological activities of Bixa orellana L.: a review. The Scientific World Journal, v. 2014, p. 1-11, 2014. 10.1155/2014/857292.
WORLD HEALTH ORGANIZATION (WHO). Central Council for Research in Ayurveda and Siddha, Department of AYUSH, Ministry of Health and Family Welfare, New Delhi: HPTLC-Fingerprint atlas of Ayurvedic Single Plant Drugs mentioned in Ayurvedic Pharmacopoeia, Vol-III and IV, p.1106. 2008.

YOKE KEONG, Y.; ARIFAH, A. K.; SUKARDI, S.; ROSLIDA, A. H.; SOMCHIT, M. N.; ZURAINI, A. Bixa orellana leaves extract inhibit bradykinin-induced inflammation via suppression of nitric oxide production. Medical Principles and Practice, v. 20, n. 2, p. 142-146, 2011.

YULIANA, M.; NGUYEN-THI, B. T.; FAIKA, S.; HUYNH, L. H.; SOETAREDJO, F. E.; JU, Y. H. Separation and purification of cardol, cardanol and anacardic acid from cashew (Anacardium occidentale L.) nut-shell liquid using a simple two-step column chromatography. Journal of the Taiwan Institute of Chemical Engineers, v. 45, n. 5, p. 218793, 2014. 10.1016/j.jtice.2014.07.012 